\title{
Mycorrhizal fungi isolated from native terrestrial orchids of pristine regions in Córdoba (Argentina)
}

\author{
Agustina Fernández Di Pardo ${ }^{1,2}$, Viviana M. Chiocchio ${ }^{2}$, Viviana Barrera ${ }^{3}$, Roxana P. Colombo ${ }^{1}$, \\ Alicia E. Martinez ${ }^{1}$, Laura Gasoni ${ }^{3}$ \& Alicia M. Godeas ${ }^{1}$ \\ 1. Facultad de Ciencias Exactas y Naturales - Universidad de Buenos Aires (UBA). Avenida Intendente Güiraldes S/N. \\ Ciudad Universitaria. 4to. Piso Laboratorio 12. Ciudad Autónoma de Buenos Aires (CABA), Argentina; \\ afernandez@agro.uba.ar, roxanacolombo@hotmail.com,martae@bg.fcen.uba.ar, godeas@bg.fcen.uba.ar \\ 2. Cát. Microbiología Agrícola y Ambiental. Facultad de Agronomía (FA-UBA) - Instituto en Biociencias Agrícolas y \\ Ambientales (INBA) - CONICET. Avenida San Martín 4453- (1417) Ciudad Autónoma de Buenos Aires (CABA), \\ Argentina; chiocchi@agro.uba.ar \\ 3. Instituto de Microbiología y Zoología Agrícola (IMYZA) - Institución Nacional de Tecnología Agropecuaria (INTA- \\ Castelar). Nicolás Repetto y De Los Reseros s/n - Hurlingham - Buenos Aires, Argentina; \\ barrera.viviana@inta.gob.ar, gasoni.amelia@inta.gob.ar
}

Received 21-IV-2014. C Corrected 01-IX-2014. Accepted 03-X-2014.

\begin{abstract}
Orchidaceae is a highly dependent group on the Rhizoctonia complex that includes Ceratorhiza, Moniliopsis, Epulorhiza and Rhizoctonia, for seed germination and the development of new orchid plants. Thus, the isolation and identification of orchid mycorrhizal fungi are important to understand the orchid-fungus relationship, which can lead to the development of efficient conservation strategies by in vivo germination of seeds from endangered orchid plants. The aim of our work was to isolate and characterize the different mycorrhizal fungi found in roots of terrestrial orchids from Córdoba (Argentina), and, to learn about the natural habit and fungal associations in the Chaco Serrano woodland pristine region. In this study, bloomed orchid root and rhizosphere soil samples were obtained in two times from Valle de Punilla during spring of 2007; samples were kept in plastic bags until processed within 48 hours, and mycorrhizal condition confirmed assessing peloton presence. A total of 23 isolates of the orchideous mycorrhizal Rhizoctonia complex were obtained. The isolates were studied based on morphological characters and ITS-rDNA sequences. Morphological characteristics as color of colonies, texture, growth rate, hyphal diameter and length and presence of sclerotia were observed on culture media. To define the number of nuclei per cell, the isolates were grown in Petri dishes containing water-agar (WA) for three days at $25^{\circ} \mathrm{C}$ and stained with Safranine-O solution. The mycorrhizal fungi were grouped into binucleate (MSGib, 10 isolates) and multinucleate (MSGim, 13 isolates) based on morphological characteristics of the colonies. We obtained the ITS1-5.8s-ITS4 region that was amplified using primers ITS1 and ITS4. Based on DNA sequencing, isolates Q23 and Q29 were found to be related to species of Ceratobasidium. Isolates Q24 and Q4 were related to the binucleated anastomosis group AG-C of Rhizoctonia sp. The rest of the isolates grouped in the Ceratobasidium clade without grouping. From our knowledge this is the first report of the association of the AG-C testers with terrestrial orchids. A high specificity was observed in the symbiotic relationship. As the mycorrhizal fungal isolates were obtained from native orchids, they could be incorporated in conservation programes of endangered orchids in Argentina. Rev. Biol. Trop. 63 (1): 275-283. Epub 2015 March 01.
\end{abstract}

Key words: Rhizoctonia, Epulorhiza, terrestrial orchids, mycorrhiza, ITS-rDNA.

Terrestrial orchids have mutualistic associations with mycorrhizal fungi that are considered necessary for seed germination and growth of orchid plants (Batty, Dixon, Brundrett, \& Sivasithamparam, 2001; Jones, 2006).
Five native species of photosynthetic terrestrial orchids are known in Chaco Serrano forest (Córdoba province, Argentina): Aa achalensis Schltr. 1920, Cyclopogon elatus (Sw.) Schltr. 1919, Sacoila lanceolata var. australis (Lindl.) 
Szlach. 1994, Habenaria hexaptera Lindl. 1835 and Pelexia bonariensis (Lindl.) Schltr. 1920. They have been previously studied for fungal colonization in roots (Richardson, Currah, \& Hambleton,1993; Girlanda et al., 2011). The habitat of these species is the forest, usually degraded because of the high level of human impact through slash and burn agriculture in the uplands. In addition to these environmental modifications, over-exploitation of forests for commercial timber use also reduces the possibilities of establishing mycorrhizal interactions, and thus affecting the distribution pattern of orchid species (Waterman, \& Bidartondo, 2008). Moreover, A. achalensis is an endemic species which has been recently included in the red list of the International Union for Conservation of Nature (Vischi, Natale, \& Villamil, 2004).

Mycorrhizal fungi of orchids form septate hyphae and coiled structures in the roots known as pelotons within cortical cells (Urcelay, Pasquín, Canovas, \& Liébana, 2005). The fungal species mycorrhizal associations have been classified as Rhizoctonia (Vilgalys, \& Cubeta, 1994; Otero, Bayman, \& Ackerman, 2005; Shan, Liew, Weatherhead, \& Hodgkiss, 2002), Ceratorhiza, Moniliopsis and Epulorhi$z a$ (Ma, Tan, \& Wong, 2003). This last genus, Epulorhiza, is one of the most common genera forming mycorrhizas with terrestrial orchids (Zelmer, \& Currah, 1997).

Since it is difficult to morphologically identify genera and species of these anamorphs, the morphological characteristics were complemented with molecular biological information to clarify better the differences between fungal isolates.

The area of Chaco Serrano Woodland in Central Argentina has been dramatically reduced during the past 30 years. Fragmentation of the woodland has reached a dramatic scale, affecting plant reproduction and impairing the regeneration of various plant species, which affects the biodiversity, the multitrophic interactions with other organisms like mycorrhizal fungi, and ultimately ecosystem functioning (Cagnolo, Cabido, \& Valladares, 2006).
In this context, the aim of our work was to isolate and characterize the mycorrhizal fungi isolated from terrestrial orchids from Córdoba (Argentina), and to learn about the natural habitat and fungal associations in a region with no human intervention.

\section{MATERIAL AND METHODS}

Area of study and plant source: The study sites were located at approximately $30^{\circ} 50^{\prime} \mathrm{S}$ $64^{\circ} 30^{\prime} \mathrm{W}$ (site A) and $30^{\circ} 51^{\prime} \mathrm{S}-64^{\circ} 33^{\prime} \mathrm{W}$ (site B) at the Valle de Punilla in Córdoba Province. Overall, the region is classified as subtropical with annual average air temperature of $16^{\circ} \mathrm{C}$ $\left(10^{\circ} \mathrm{C}\right.$ in winter and $22^{\circ} \mathrm{C}$ during summer) and total annual precipitation between 700 and $800 \mathrm{~mm}$, falling mainly in the warm season (November-March). Roots of orchid species were collected between November-December 2007, when the plants were in bloom. Rhizosphere soil and whole orchid plants were collected from Huerta Grande, Villa Giardino, La Falda and Capilla del Monte at the Valle de Punilla in Córdoba Province. The samples were kept in plastic bags and later processed within 48h (Fracchia et al., 2009).

Mycorrhizal colonization: In order to confirm mycorrhization, presence of peloton structure was assessed. Orchid roots were washed with tap water and cleared using 10\% (w/v) $\mathrm{KOH}$ solution. Roots with fungal structures were subsequently stained with $0.05 \%$ (w/v) trypan blue in lactoglycerol (1:1:1 lactic acid, glycerol, and water) following procedures described by Phyllips and Hayman (1970). Finally, transversal sections of roots were prepared and observed under a Nikon (Optiphot-2) light binocular microscope at a 100X magnification.

Fungal isolation: Mycorrhizal fungi were isolated from roots of 23 different orchid plants. The roots were rinsed with tap water to remove debris, and were cut into $1 \mathrm{~cm}$ length segments. The surfaces of these root segments were sterilized in $10 \%$ sodium hypochlorite 
solution for $3 \mathrm{~min}$; then segments were rinsed three times with sterile distilled water. The segments were placed on potato dextrose agar (PDA) in Petri dish plates. The plates were incubated in the dark at $25^{\circ} \mathrm{C}$, and microscopic observations were made daily during seven days (Fracchia, Silvani, Flachsland, Terada, \& Sede, 2014). Fungal hyphal tips emerging from root tissues and cells containing peloton structure were transferred to fresh PDA and were further cultivated.

The pure cultures were kept, for further use, on PDA and malt extract-agar (MEA) in tubes containing soil: oat bran $(1: 2)$ at $4^{\circ} \mathrm{C}$, and in eppendorf tubes with wheat seeds at $-20^{\circ} \mathrm{C}$. All isolates were included in the collection of the Instituto de Microbiología y Zoología Agrícola (IMyZA-INTA).

Morphological and cytological observations: Morphological characteristics determined in the cultures were: the color of colonies, texture, growth rate, number of nuclei per cell, hyphal diameter and length and presence of sclerotia on PDA and MEA. In order to observe the number of nuclei per cell, the isolates were grown in Petri dishes containing water-agar (WA) for three days at $25^{\circ} \mathrm{C}$ and nuclei were stained with Safranine-O solution (Bandoni, 1979).

Growth rates were determined on PDA by measuring the colony diameter in two perpendicular directions every $24 \mathrm{~h}$ for eight days. The colony diameter includes the diameter of the initial inoculum $(5 \mathrm{~mm})$. The measurements were carried out in triplicate. Growth data were analyzed with ANOVA and means of different subgroups were compared by Tukey's test on days four and six. All statistical analyses were performed using the Infostat statistical software (Di Rienzo et al., 2013).

The potential relationship between the mycorrhizal fungal isolates and orchid species was compared by Fisher's Exact Test, according to data shown in Table 1.

Molecular analysis: Mycelia grown in potato broth $(2 \mathrm{~mL})$ was placed in a $-80^{\circ} \mathrm{C}$ freezer for two minutes, then transfered to a water bath at $95^{\circ} \mathrm{C}$ for one minute and macerated with glass beads three times to homogenization. DNA was precipitated with $100 \%$ chloroform solution (Harju, Fedosyuk, \& Peterson, 2004). The genomic DNA was quantified with a spectrophotometer at $260 \mathrm{~nm}$ and at $280 \mathrm{~nm}$ to check interfering substances.

The ITS1-5.8s-ITS4 region was amplified using primers ITS1 and ITS4 (White, Bruns, Lee, \& Taylor, 1990). In a $50 \mu \mathrm{L}$ total volume, 10-100ng genomic DNA was used as template, using $20 \mathrm{mM}$ Tris- $\mathrm{HCl}(\mathrm{pH} 8.4), 50 \mathrm{mM}$ $\mathrm{KCl}, 0.2 \mathrm{mM}$ dNTPs, $0.2 \mu \mathrm{M}$ primer, $3 \mathrm{mM}$ $\mathrm{MgCl}_{2}$, and $0.2 \mathrm{U} / \mu \mathrm{L}$ High Fidelity Platinum taq polymerase (Invitrogen). The amplification program was as follows: $1 \mathrm{~min}$ at $94^{\circ} \mathrm{C}, 1$ cycle; $15 \mathrm{~s}$ at $94^{\circ} \mathrm{C}, 15 \mathrm{~s}$ at $58^{\circ} \mathrm{C}, 15 \mathrm{~s}$ at $68^{\circ} \mathrm{C}$, 30 cycles; $7 \mathrm{~min}$ at $72^{\circ} \mathrm{C}, 1$ cycle. Aliquots of the corresponding amplification products were separated by electrophoresis in $1.5 \%$ agarose and stained with ethidium bromide and visualized using an UV transilluminator.

The PCR products were purified using the Geneclean Spin kit (Qbiogene), eluted in $30 \mu \mathrm{L}$ ultrapure water. Sequencing was conducted under BigDyeTM Terminator v 3.1 (Applied Biosystems) based on Sanger's method. The reacted products were purified using ethanol precipitation and run with Genetic Analyzer 3130xl at Unidad de Genómica - Instituto de Biotecnología - CICVyA.

For the phylogenetic analysis the multiple alignments were performed with ClustalW in MEGA version 4.0 (Tamura, Dudley, Nei, \& Kumar, 2007) among 11 rDNA-ITS sequences from our isolates and the following sequences retrieved from GenBank: Waitea circinata (EF429315); Rhizoctonia zeae (AB213595); Epulorhiza albertensis (AF345563); Epulorhiza anaticula (EU218891); Tulasnella calospora (DQ388045); Rhizoctonia solani AG6-HG-I (AF354102); AG-8 (AF153795); AG-3 (AF153771); AG-10 (AF153800); Ceratobasidium albasitensis (HQ680963); Ceratobasidium sp. (JF912482); AG-B(0) (DQ102430); AG-H (AF354089); AG-C (AB290021); AG-12 (AF153805); AG-4 (DQ102449); 
TABLE 1

Morphological characteristics of the colonies, location and accession number to the GeneBank

\begin{tabular}{|c|c|c|c|c|c|c|c|}
\hline Host & Site $^{1}$ & $\begin{array}{l}\text { Fungal } \\
\text { isolate }\end{array}$ & $\begin{array}{l}\text { Colony } \\
\text { morphology }\end{array}$ & $\begin{array}{l}\text { Nuclei number } \\
\text { per cell }{ }^{2}\end{array}$ & $\begin{array}{c}\text { Sclerotia } \\
\text { formation (yes/no) }\end{array}$ & $\begin{array}{l}\text { Morphological } \\
\text { subgroup }^{3}\end{array}$ & $\begin{array}{c}\text { Accesion } \\
\text { Number GenBank }\end{array}$ \\
\hline \multirow[t]{13}{*}{ Sacoila australis } & HG & Q1 & Dark brown & $\mathrm{BN}$ & No & MSG4b & \\
\hline & VG & Q7 & Dark brown & $\mathrm{BN}$ & No & MSG4b & \\
\hline & $\mathrm{HG}$ & Q20 & Dark brown & BN & No & MSG4b & \\
\hline & $\mathrm{CM}$ & Q22 & Dark brown & $\mathrm{BN}$ & No & MSG4b & \\
\hline & HHG & Q28 & Dark brown & $\mathrm{BN}$ & Yes & MSG4b & HQ713496 \\
\hline & VG & Q10 & Light brown & $\mathrm{BN}$ & Yes & MSG1b & HQ713498 \\
\hline & VG & Q16 & Light brown & $\mathrm{BN}$ & No & MSG2b & \\
\hline & $\mathrm{VG}$ & Q6 & Light brown & $\mathrm{MN}$ & Yes & MSG4m & HQ713506 \\
\hline & VG & Q8 & Light brown & MN & Yes & MSG4m & HQ713501 \\
\hline & HG & Q5 & Dark brown & MN & No & MSG3m & \\
\hline & VG & Q9 & Dark brown & $\mathrm{MN}$ & Yes & MSG3m & HQ713500 \\
\hline & VG & Q15 & Dark brown & MN & No & MSG3m & \\
\hline & VG & Q25 & Golden yellow & MN & No & MSG5m & \\
\hline Pelexia bonariensis & $\mathrm{HG}$ & Q21 & Dark brown & $\mathrm{BN}$ & Yes & MSG4b & HQ713497 \\
\hline \multirow[t]{4}{*}{ Aa achalensis } & $\mathrm{HG}$ & Q23 & Golden yellowish & $\mathrm{BN}$ & Yes & MSG5b & HQ713403 \\
\hline & $\mathrm{HG}$ & Q24 & White & $\mathrm{BN}$ & No & MSG3b & HQ713499 \\
\hline & LF & $\mathrm{Q} 2$ & White & MN & No & MSG1m & \\
\hline & LF & Q13 & Light brown & MN & Yes & MSG4m & HQ713505 \\
\hline \multirow[t]{2}{*}{ Cyclopogon elatus } & HG & Q26 & Golden yellow & $\mathrm{MN}$ & No & MSG5m & \\
\hline & $\mathrm{HG}$ & Q29 & Golden yellow & $\mathrm{MN}$ & Yes & MSG5m & HQ713504 \\
\hline \multirow[t]{3}{*}{ Habenaria hexaptera } & VG & $\mathrm{Q} 4$ & White & MN & No & MSG1m & HQ713502 \\
\hline & VG & Q30 & White & $\mathrm{MN}$ & No & MSG1m & \\
\hline & $\mathrm{HG}$ & Q27 & Dark brown & $\mathrm{MN}$ & No & MSG2m & \\
\hline
\end{tabular}

1. Locations: HG: Huerta Grande, VG: Villa Giardino, CM: Capilla del Monte; LF: La Falda.

2. Number of nuclei per cell: BN: binucleated, $\mathbf{M N}$ : multinucleated.

3. MSGij: $\mathbf{i}=$ subgroup number; $\mathbf{j}=$ binucleated or multinucleated.

AG-F (DQ102440); AG-Fb (AB219145.1); AG-L (AF354093); AG-O (AF354094); AG-G (AB196646); AG-A (DQ102417). Cladogram construction was done with NONA (Goloboff, 1999) in Winclada (Nixon, 2002). Heuristic search strategy was performed using Multiple TBR + TBR with 10000 hold and 1000 replicates in a matrix of 35 taxa with 397 informative characters. Bootstrap values were calculated from 1000 replicates; they will be shown as a number above branches and abbreviated as "bv".

\section{RESULTS}

Isolation of mycorrhizal fungi from orchid roots: All the orchid roots were of characteristic coarse appearance (Fig. 1A, example of Sacoila australis). All roots were colonized by mycorrhizal fungi, evidenced by the presence of mycorrhizal structures (Fig 1B) and of peloton structures in cells (Fig. 1C). A total of 23 strains were obtained with characteristic morphology resembling the Rhizoctonia group. Ten isolates showed two nuclei per cell, whereas 13 showed multinucleate cells (Table 1).

Morphological identification: The isolated fungi were grouped into morphological subgroup binucleate (MSG $\mathrm{b}$ ) and multinucleate $\left(\mathrm{MSG}_{i} \mathrm{~m}\right)$ isolates. Further grouping was by colour of the colonies (Table 1). One-factor ANOVA and Tukey contrasts showed that there 

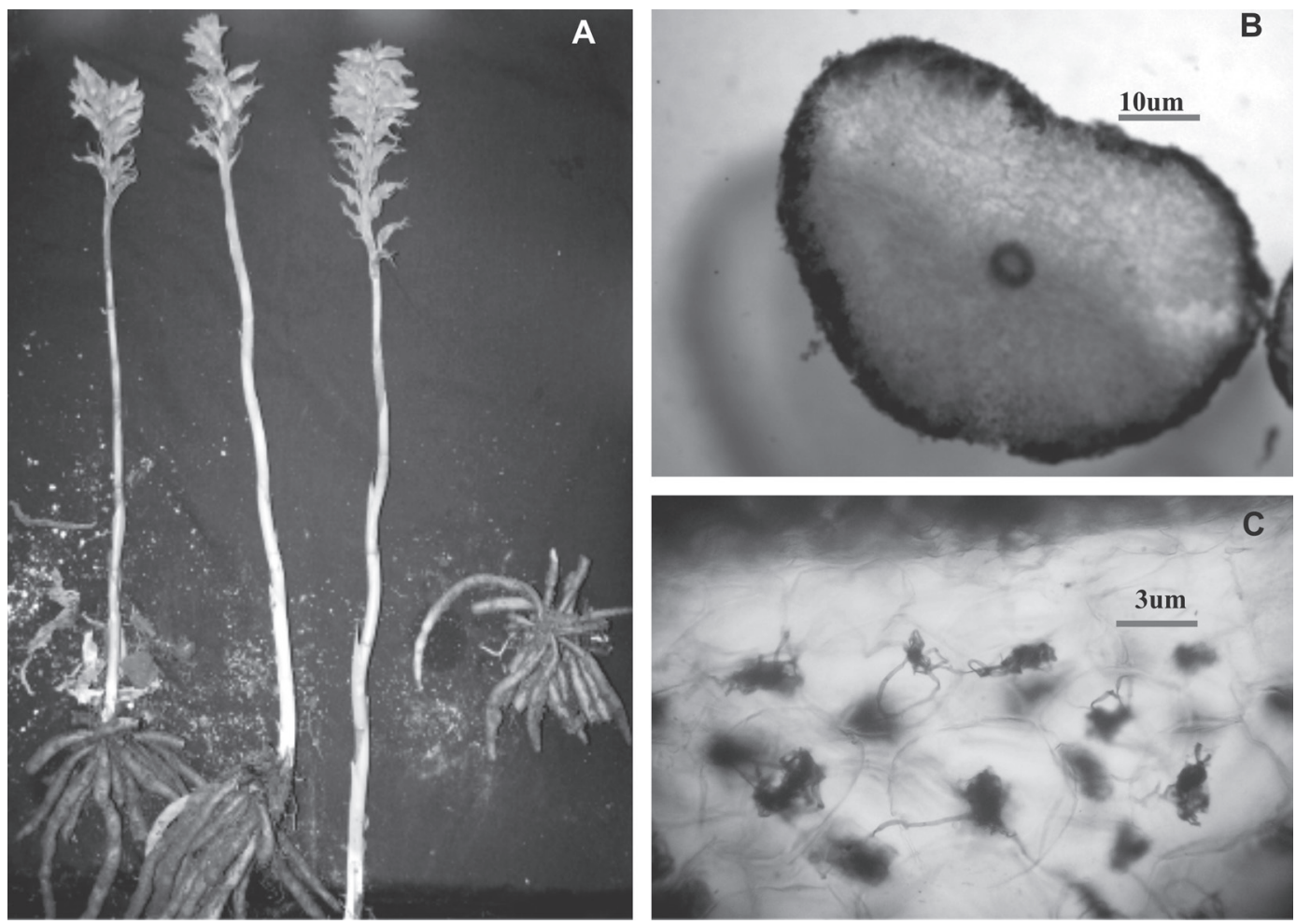

Fig. 1. A. Sacoila australis; B. Transversal section of S. australis root (A10X); C. Intraradical structures (pelotons) in S. australis root (A:40X).

were no significant differences were found in the length and width of hyphae among all the isolates of mycorrhizal fungi Sclerotia formation on PDA was observed in the isolates: Q23, Q9, Q8, Q28, Q21, Q10, Q13, Q6 and Q29.

Growth rate was analysis with one-factor ANOVA and Tukey contrasts showed significant different among binucleate morphological subgroups on days four and six $\left(\mathrm{F}_{4,1}=13.94\right.$, $\mathrm{p}<0.01)$. Also, in the multinucleate subgroups the one-factor ANOVA and Tukey contrasts showed significant differences among subgroups on days four $\left(\mathrm{F}_{4,1}=8.19, \mathrm{p}<0.01\right)$ and $\operatorname{six}\left(\mathrm{F}_{4,1}=6.39, \mathrm{p}<0.05\right)$ (Table 2).

Molecular data analysis: Amplification products 600 to $800 \mathrm{bp}$ size from ITS1-5.8sITS4 region were obtained from one isolate of each subgroup. The sequences of the fungi obtained during this study were deposited at GenBank (Table 1).
TABLE 2

Growth kinetics of isolates

\begin{tabular}{ccc}
$\begin{array}{c}\text { Morphological } \\
\text { subgroup }\end{array}$ & Day $4(\mathrm{~cm})^{1}$ & Day 6 (cm $)^{1}$ \\
MSG1b & $4.4 \pm 0^{\mathrm{a}}$ & $8.6 \pm 0^{\mathrm{b}}$ \\
MSG2b & $4.9 \pm 0^{\mathrm{c}}$ & $8.6 \pm 0^{\mathrm{b}}$ \\
MSG3b & $5.8 \pm 0^{\mathrm{bd}}$ & $8.6 \pm 0^{\mathrm{bc}}$ \\
MSG4b & $5.5 \pm 0.4^{\mathrm{d}}$ & $8.6 \pm 0^{\mathrm{bc}}$ \\
MSG5b & $6.1 \pm 0^{\mathrm{bd}}$ & $8.6 \pm 0^{\mathrm{bd}}$ \\
MSG1m & $4.5 \pm 0.4^{\mathrm{a}}$ & $7.8 \pm 0.3^{\mathrm{a}}$ \\
MSG2m & $4 \pm 0^{\mathrm{a}}$ & $7.3 \pm 0^{\mathrm{c}}$ \\
MSG3m & $5.5 \pm 0.3^{\mathrm{bc}}$ & $8.6 \pm 0^{\mathrm{bd}}$ \\
MSG4m & $5.1 \pm 1.4^{\mathrm{b}}$ & $7.8 \pm 1.5^{\mathrm{d}}$ \\
MSG5m & $5 \pm 0.5^{\mathrm{b}}$ & $8.2 \pm 0.3^{\mathrm{d}}$ \\
\hline
\end{tabular}

1. Mean values, from isolates belonging to the same morphological subgroup, of colony diameter in $\mathrm{cm}$, including the diameter of initial inoculum, with their respective standard deviation, measured on days 4 and 6 for the morphological subgroups. The mean values were obtained from three independent experiments. Different letter indicates significantly differences $(\mathrm{p} \leq 0.05)$ according to one-factor ANOVA and Tukey test. 

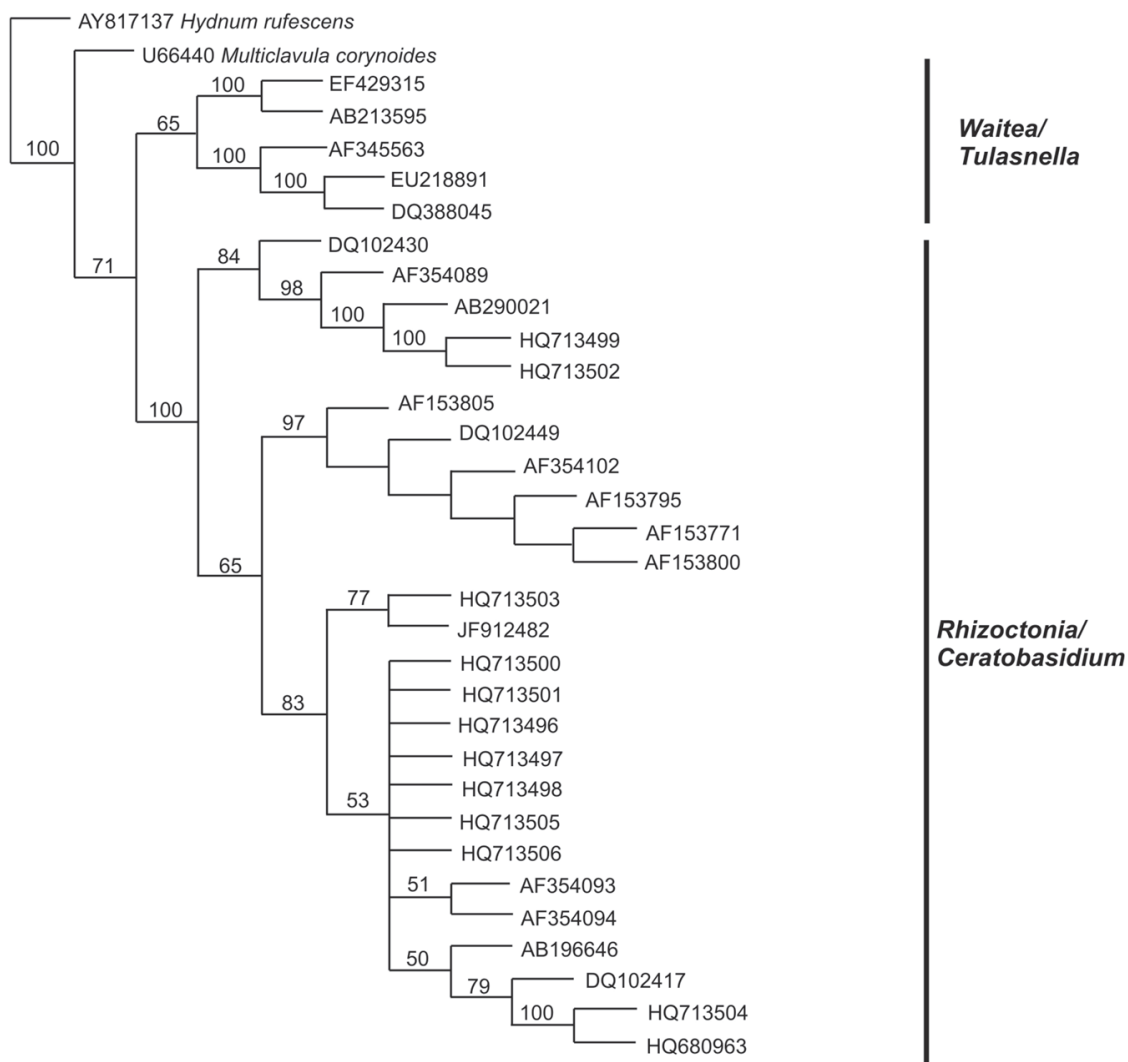

Fig. 2. Genetic relationships among the isolates from terrestrial orchid's roots based on the internal transcribed spacer sequences.

The Parsimony Analysis gave six most likely parsimonious trees, length 1218 steps with Consistency Index $=60$ and Retention Index $=68 ; 108$ suboptimal trees were generated. The strict consensus analysis (Fig. 2) generated 12 clades. The topology shows two main clades: one corresponds to fungal isolates of Epulorhiza/Waitea $(65 \% \mathrm{bv})$ and the other to isolates of the Rhizoctonia / Ceratobasidium group $(100 \% \mathrm{bv})$.

The native isolates grouped within the second clade. The isolate Q29 grouped with C. albasitensis with $100 \% \mathrm{bv}$. The isolate Q23 grouped $(77 \% \mathrm{bv})$ with Ceratobasidium sp. EE-2011 isolate OP7. The isolates Q24 and Q4 grouped with high bootstrap value $(100 \%)$ with Ceratobasidium sp. AG-C reference sequence.
The rest of the isolates grouped in the Ceratobasidium clade without grouping.

The AG-Bo, AG-A, and AG-12 were found in separate clades and none of them were related with our isolates.

Relationship among different isolates and their corresponding hosts: Fisher's test showed significant differences $(\mathrm{p}<0.0001)$ for the $\mathrm{MSG}_{\mathrm{i}} \mathrm{b}$ and $\mathrm{MSG}_{\mathrm{i}} \mathrm{m}$ associated to different species of orchids. The specificity among the orchid species collected at the Valle de Punilla and the strains isolated showed the following distribution: $H$. hexaptera and $C$. elatus were colonized by only one group, AG-C (AB290021) and C. albasitensis (HQ680963), respectively. On the other hand, A. achalensis 
roots were colonized by AG-C and Ceratobasidium sp. (JF912482).

\section{DISCUSSION}

Based on the morphological description of the colonies and the growth rate in PDA, it was possible to classify the isolates in ten subgroups. Both binucleate and multinucleate groups showed significant differences in growth rates among subgroups. Isolates belonging to the same binucleate subgroup, show no significative differences in growth rates. On the other hand, the multinucleate growth kinetics was variable for each isolate belonging to the same subgroup.

The phylogenetic analysis of the ITS sequences showed that the native isolates were grouped within the Ceratobasidium/Rhizoctonia Clade, independently of the nuclear number. The isolate Q29 is highly similar to $C$. albasitensis showing that it could belong to that species. Eisold and Grosch (2010) obtained $C$. albasitensis, identified as isolate 26/5, from root tips of Dactylorhiza purpurella, so this species is related to orchid's species (http:// dpg.phytomedizin.org/fileadmin/daten/04_Verlag/03_JB/Jahresbericht_2010.pdf).

The isolate Q23 is similar to the Ceratobasidium strain EE-2011 OP7 isolated from roots of Orchis purpurea (Girlanda et al., 2011). Only isolates Q24 and Q4 were related to known binucleate AG, corresponding to AG-C (AB290021). Although one of them (Q4) is a multinucleate strain, they both present similar morphological characteristics.

It is important to highlight that none of the isolates correspond to the anastomosis groups that are associated with orchids (AGA; AG-B(0), AG-6 and AG-12). We want to point out that this is the first report about the association between the AG-C and terrestrial orchids. The only report we found is in strawberry (Fang, Finnegan, \& Barbetti, 2013). As the strains were isolated from native orchids, we suggest including them as new testers for terrestrial orchids in Argentina.
On the other hand, the rest of our strains did not form a consolidated clade among them and with known tester strains of Rhizoctonia sp. This result indicates that our isolates may represent a polyphyletic group. However, most AGs have been reported as representing monophyletic units (Vilgalys, \& Cubeta, 1994; Shan et al., 2002).

In agreement with the results reported by Bonnardeaux et al. (2007), we observed different behavior (Bonnardeaux et al., 2007). While some orchid species, such as $C$. elatus and $P$. bonariensis, established associations with only one subgroup, others such as $S$. australis were colonized by more than one subgroup. The differences among the subgroups of Rhizoctonia indicate a preference for the colonization of some orchid species. S. australis is the species that mainly contributed to this difference. Although in other species this behavior cannot be ruled out, these results must be confirmed with a larger number of isolates.

McCormick, Whigham, and O'Neill, (2004), Otero et al. (2005), McCormick Whigham, Sloan, O'Malley, and Hodkinson (2006) and Dearnaley (2007) have established that there is a considerable variation in the colonization of terrestrial orchid roots (Dearnaley, 2007; McCormick et al., 2004; Otero et al., 2005, McCormick et al., 2006). Some species are associated with different fungi along their life cycles. McCormick et al. (2006) reported that Goodyera pubescens is able to change the symbiont under unfavorable environmental conditions, in particular, those that lead to alterations in the soil microbial communities (McCormick et al., 2006). In cases where a specific mycorrhizal association is required, the availability of the appropriate symbiont and critical environmental factors needed for orchid survival are important in their distribution as well as in the population size. Species associated with a reduced number of $A G$ are more susceptible to changes in the environment that can lead to the disappearing of the suitable mycorrizal fungi.

The results of this study will contribute to the understanding of the orchid-fungus 
relationship and consequently to the development and improvement of conservation strategies for endangered orchid species in pristine regions, currently degraded after the high human impact level.

\section{ACKNOWLEDGMENTS}

The authors wish to thank to University of Buenos Aires (UBA) and the Consejo Nacional de Investigaciones Científicas y Técnicas (CONICET) for their financial support.

\section{RESUMEN}

Hongos micorrízicos aislados de orquídeas terrestres nativas de regiones pristinas en Córdoba (Argentina). La Familia Orchidaceae se encuentra estrechamente relacionada con hongos micorrízicos que pertenecen al complejo Rhizoctonia, e incluyen los géneros Ceratorhiza, Moniliopsis, Epulorhiza y Rhizoctonia. Esta asociación es esencial para el desarrollo de nuevas plantas ya que favorecen el proceso de germinación de las semillas. Por lo tanto, el conocimiento de la naturaleza de esta interacción es importante para que los resultados de los programas de conservación de orquídeas sean efectivos. La fragmentación del bosque Chaqueño Serrano en el centro de Argentina, ha alcanzado un punto crítico en los últimos años, afectando el funcionamiento del ecosistema. El objetivo de este trabajo fue: a) aislar y caracterizar hongos micorrízicos presentes en orquídeas terrestres de la provincia de Córdoba (Argentina) y b) conocer el hábitat natural y las asociaciones fúngicas que se establecen en esta región prístina. A partir de las raíces de orquídeas terrestres, se obtuvieron 23 aislamientos de hongos micorrízicos que pertenecen al complejo Rhizoctonia. Estos aislamientos fueron caracterizados con base en caracteres morfológicos y moleculares. Las características morfológicas (color y textura de las colonias, cinética de crecimiento, diámetro y largo de la hifa y presencia de esclerocios) fueron observados en PDA y MEA a $25^{\circ} \mathrm{C}$. El número de núcleos por célula se observó en cultivos crecidos en AA (agar-agua) y teñidos con una solución de Safranine-O. La región ITS se amplificó usando los primers ITS1 e ITS4. Con base en las características morfológicas de la colonia, los aislamientos fueron agrupados en binucleados (MSGib) y multinucleados (MSGim). De acuerdo al cladograma obtenido con las secuencias de $\mathrm{ADN}$, los aislamientos Q23 y Q29 están relacionados a especies de Ceratobasidium, aisladas de raíces de orquídeas. Los aislamientos Q24 y Q4 se asocian con el grupo de anastomosis de Rhizoctonia AG-C. Finalmente, se observó una alta variabilidad en el grado de especificidad existente en la simbiosis que se establece entre las raíces de estas orquídeas terrestres y los aislamientos obtenidos a partir de ellas. Este es el primer reporte de la asociación entre el grupo de anastomosis AG-C y orquídeas terrestres. Dado que estos aislamientos se obtuvieron de orquídeas terrestres nativas, podrían ser incorporados como nuevos patrones para micorrizas de orquídeas terrestres en Argentina. Este trabajo contribuye al conocimiento de la relación simbiótica que se establece entre orquídeas y hongos micorrízicos, así como también al desarrollo de estrategias de conservación de orquídeas terrestres nativas del bosque Chaco Serrano.

Palabras clave: Rhizoctonia, Epulorhiza, orquídeas terrestres, micorrizas, ITS-rDNA.

\section{REFERENCES}

Bandoni, R. J. (1979). Safranin O as a rapid nuclear stain for fungi. Mycologia, 71, 873-874.

Batty, A. L., Dixon, K. W., Brundrett, M., \& Sivasithamparam, K. (2001). Constraints to symbiotic germination of terrestrial orchid seed in a mediterranean bushland. New Phytologist, 152(3), 511-520.

Bonnardeaux, Y., Brundrett, M., Batty, A., Dixon, K., Koch, J., \& Sivasithamparam, K. (2007). Diversity of mycorrhizal fungi of terrestrial orchids: compatibility webs, brief encounters, lasting relationships and alien invasions. Mycological Research, 3, 51-61.

Cagnolo, L., Cabido, M., \& Valladares, G. (2006). Plant species richness in the Chaco Serrano Woodland from central Argentina: ecological traits and habitat fragmentation effects. Biological Conservation, 132, 510-519.

Dearnaley, J. D. W. (2007). Further advances in orchid mycorrhizal research. Mycorrhiza, 17, 475-48.

Di Rienzo, J. A., Casanoves, F., Balzarini, M. G., Gonzalez, L., Tablada, M., \& Robledo, C. W. (2013). Infostat (Versión 2013). Grupo Infostat, Fca, Universidad Nacional De Córdoba, Argentina. Retrieved from http://www.infostat.com.ar.

Eisold, A. M., \& Grosch, R. (2010). Root tips of Dactylorhiza species. Ökologisch, M., \& Mykorrhiza Symbiose, R. PG Mikrobielle Symbiose N. Zusammenfassungen der Arbeitskreisbeiträge. Retrieved from http://dpg. phytomedizin.org/fileadmin/daten/04_Verlag/03_JB/ Jahresbericht_2010.pdf

Fang, X., Finnegan, P. M., \& Barbetti, M. J. (2013). Wide Variation in Virulence and Genetic Diversity of Binucleate Rhizoctonia Isolates Associated with Root Rot of Strawberry in Western Australia. PLoS ONE, 8(2), 1-14.

Fracchia, S., Aranda, A., Gopar, A., Silvani, V., Fernandez, L., \& Godeas, A. (2009). Mycorrhizal status of plant species in the Chaco Serrano Woodland from central Argentina. Mycorrhiza, 19, 205-214. 
Fracchia, S., Silvani, V., Flachsland, E., Terada, G., \& Sede, S. (2014). Symbiotic seed germination and protocorm development of Aa achalensis Schltr., a terrestrial orchid endemic from Argentina. Mycorrhiza, 24(1), 35-43.

Girlanda, M., Segreto, R., Cafasso, D., Liebel, H., Rodda, M., Ercole, E., Cozzolino, S., Gebauer, G., \& Perotto, S. (2011). Photosynthetic Mediterranean meadow orchids feature partial mycoheterotrophy and specific mycorrhizal associations. American Journal of Botany, 98(7), 1148-1163.

Goloboff, P. A. (1999). NONA (ver. 2.0). Tucumán, Argentina: published by the author.

Jones, D. L. (2006). Miscellaneous new species of Australian Orchidaceae Austral. Orchid Research, 5, 45-111.

Harju, S., Fedosyuk, H., \& Peterson, K. R. (2004). Rapid isolation of yeast genomic DNA. Bust n'Grab. BMC Biotechnology, 4-8.

Ma, M., Tan, T. K., \& Wong, S. M. (2003). Identification and molecular phylogeny of Epulorhiza isolates from tropical orchids. Mycological Research, 107, 1041-1049.

McCormick, M. K., Whigham, D. F., \& O’Neill, J. (2004). Mycorrhizal diversity in photosynthetic terrestrial orchids. New Phytologist, 163(2), 425-438.

McCormick, M. K., Whigham, D. F., Sloan, D., O’Malley, K., \& Hodkinson, B. (2006). Orchid-fungus fidelity: a marriage meant to last? Ecology, 87(4), 903-911.

Nixon, K. C. (2002). WinClada (version 1.00.08). Ithaca, NY: Published by the author, p. 29.

Otero, J. T., Bayman, P., \& Ackerman, J. D. (2005). Variation in mycorrhizal performance in the epiphytic orchid Tolumnia variegata in vitro: the potential for natural selection. Evolutionary Ecology, 19, 29-43.

Phyllips, J. M., \& Hayman, D. S. (1970). Improved procedures for clearing roots and staining parasitic and vesicular-arbuscular mycorrhizal fungi for rapid assessment of infection. Transactions of the British Mycological Society, 55, 158-161.

Richardson, K. A., Currah, R. S., \& Hambleton, S. (1993). Basidiomycetous endophytes from the roots of Neotropical epiphytic Orchidaceae. Lindleyana, $8,127-137$.

Shan, X. C., Liew, E. C. Y., Weatherhead, M. A., \& Hodgkiss, I. J. (2002). Characterization and taxonomic placement of Rhizoctonia-like endophytes from orchid roots. Mycologia, 94, 230-239.

Tamura, K., Dudley, J., Nei, M., \& Kumar, S. (2007). MEGA4: Molecular Evolutionary Genetics Analysis (MEGA) software version 4.0. Molecular Biology and Evolution, 24, 1596-1599.

Urcelay, C., Pasquín, R., Canovas, S., \& Liébana, V. (2005). Colonización micorrícica en tres especies de Orquídeas nativas de las Sierras de Córdoba, Argentina. Kurtziana, 31(1-2), 51-57.

Vilgalys, R., \& Cubeta, M. A. (1994). Molecular Systematics and Population Biology of Rhizoctonia. Annual Review of Phytopathology, 32, 135-155.

Vischi, N., Natale, E., \& Villamil, C. (2004). Six endemic plant species from central Argentina: an evaluation of their conservation status. Biodiversity and Conservation, 13, 997-1008.

Waterman, R. J., \& Bidartondo, M. I. (2008). Deception above, deception below: linking pollination and mycorrhizal biology of orchids. Journal of Experimental Botany, 59(5), 1085-1096.

White, T. J., Bruns, T., Lee, S., \& Taylor, J. (1990). Amplification and direct sequencing of fungal ribosomal RNA genes for phylogenetics. In M. A. Innis, D. H. Gelfand, J. J. Shinsky, \& T. J. White (Eds.), PCR protocols: A guide to methods and applications (pp. 315-322). San Diego: Academic.

Zelmer, C. D., \& Currah, R. H. (1997). Symbiotic germination of Spiranthes lacera (Orchidaceae) with a naturally occuring endophyte. Lindleyana, 12, 142-148. 
